\title{
The economics of agricultural development: what have we learned?
}

James ROUMASSET ${ }^{1}$

Department of Economics, University of Hawaii at Manoa, 2424, Maile Way, Honolulu, HI 96822 <jimr@hawaii.edu>

\begin{abstract}
Agricultural development thinking has gone through several stages of fad and fancy, often without an understanding of previous fallacies. Its current doldrums are unfortunate given the unrivaled importance of agricultural development for poverty reduction in most development countries. After reviewing several policy and program areas, lessons are synthesized, and a forward-looking research framework suggested, especially regarding role of specialization in the evolution of economic organization. The corresponding role of government is seen to be the facilitation of economic cooperation, rather than social engineering.
\end{abstract}

Key words: agricultural development, development economics

ment is not a high status enterprise in departments of agricultural and resource economics. This leaves agricultural development twice marginalized in the academe, and nonacademic institutions may be hard pressed to fill the void, despite the heroic efforts of a few stalwart crusaders and organizations such as IAAE. The following review of agricultural development thinking is offered in the spirit that understanding of previous thinking may help to identify new frontiers that today's researchers will find suitably promising and challenging.

\section{Fads and fancies}

\section{Development economics}

Inasmuch as the Economics of Agricultural Development is partly derivative of Development Economics generally, we begin with a characterization of development thinking. In the 1950s and early Economic Development was dominated by the planning mentality. The Harrod-Domar model was in vogue. The idea was to choose a target growth rate, compute the investment requirement, and apportion the investment by sectors and fill the resulting saving and foreign exchange gaps with repression and foreign aid. This was "utopian social engineering" Popper at its worst [2].

As economic development thinking evolved to incorporate the dualistic view of the economy (Lewis/Fei-Ranis) [3, 4], the focus shifted to import substitution stimulated by protective tariffs, exchange-rate controls, and selective investment incentives. These strategies led to the inevitable capital-intensive industrialization of finishing-stage import substitutes, followed by economic stagnation and unemployment. Without denouncing dualism, the World Bank dubbed the 70s the "growth with equity" decade. Counteracting market failure with Pigouvian interventionism came into vogue as did the Samuelsonian trade-off between equity and efficiency. Subsidies were considered appropriate instruments of development. Agricultural and rural development were pursued through agricultural research/extension and investments in rural infrastructure.

Again, development performance failed to keep up with expectations engendered by the new paradigm. The focus on market failure gave way to awareness of government failure. Partly through disappointment with the results and partly through changing political ideology, the Reagan 80s ushered in a new era of development thinking and development assistance. The World Bank was characterized as leading the Washington consensus, roughly described as pursuing policies that "privatize and get the prices right" The Bank provided structural adjustment loans to induce trade liberalization and market fundamentalism. The 80 s and 90 s also witnessed rapid progress in international economic coordination such as the various rounds of GATT negotiations and increasing prominence of the WTO as well as various regional trade agreements. As trade barriers, transportation costs, and communication costs fell (the last corresponding in particular with the IT revolution) the world economy was increasingly globalized and participants therein by and large experienced more rapid economic growth and absolute poverty reduction. But once more the pendulum had swung too far. The enthusiasts for tariff reduction ignored market limitations and neglected to find compensating revenue sources. Negotiators of structural adjustment loans took the tariff reductions they could get, 
even when it meant that even more distortionary non-tariff barriers replaced them. As the Washington Consensus faded and politics changed with the Clinton administration, a Post Washington Consensus formed around the fascination with the East Asian Miracle. Markets were now thought to be incapable of coordinating investments and information was thought to be so pervasively incomplete that market outcomes could always be improved upon by coercion. The centerpiece of the paradigm is the Greenwald-Stiglitz theorem [5] according to which market equilibrium in the face of imperfect information is not "constrained Pareto efficient." That is, government intervention that is informed by an understanding of market failure can increase economic efficiency, even though government itself has limited information [6].

Stiglitz's new information economics has been formalized largely in an institutional vacuum, however, and has neither been successful in explaining the statistical patterns and rich tapestry of economic institutions nor designing effective policy reforms. For example, Stiglitz's theorem of share tenancy, a forerunner of the Greenwald-Stiglitz theorem, has been discredited both on theoretical grounds and as a possible framework for explaining actual patterns of agricultural contracts [7]. Moreover, the alleged victories of policy design, such as the East Asian Miracle, have allegedly been ex post rationalizations of policies that evolved independently of the new information economics ${ }^{2}$. Stiglitz also notes that all that globalizes is not gold, especially for the world's poor. Partially to blame are international economic institutions that are quick to serve the interests of the advanced industrialized countries and slow to do the same for those of the developing world [9].

One alternative to the interventionist new information economics is the New Institutional Economics (NIE), sometimes called transaction cost economics. This perspective focuses on the natural pattern of economic evolution as a progression of ever-successive rounds of specialization and organizational complexity [10, 11]. From the perspective of the NIE, the role of government is to facilitate this evolution by providing the constitutional infrastructure for economic cooperation - the rule of law and institutions of governance that facilitate both bilateral and multilateral contracting. This contrasts starkly with both the Pigouvian (firstbest) and Stiglitz's (second- best) versions of market socialism [13].

\footnotetext{
${ }^{2}$ See e.g. Roumasset and Barr [8] for an alternative explanation of the so-called miracle, based on the theory of economic cooperation reform, not just small communities and NGO's.
}

The current decade is becoming known for community-driven development (CDD), but that moniker means different things to different authors. The Wolfenson World Bank was known for celebrating the Voices of the Poor, which led Larry Summers, provocateur par excellance, to remark that the Bank was "losing its analytical edge." Binswanger [12] suggests an interpretation with potentially sound foundations, however, emphasizing the need for all segments of society to be involved in politically feasible.

The Bush administration has articulated a development policy that embraces freedom, security, and opportunity, but has of yet neither fleshed out its economic foundations nor manifested it in actual programs (USAID [14]). Jeffrey Sachs [15] proposes shock therapy - a package economic reforms funded by Western aid and loans that evokes images from the 50 s of social engineering and the big push. As the intellectual focus and program emphasis changed from decade to decade, there was little sense of learning from past mistakes. "Spending \$2.3 trillion (measured in today's dollars) in aid over the past five decades has left the most aid-intensive regions, like Africa, wallowing in continued stagnation; it's fair to say this approach [the big plan] has not been a great success" [16]. Indeed policies and programs were not necessarily abandoned but added to. For example as the emphasis changed from import substitution to "growth with equity" tariff protection was left in place even as rural development programs took off, leading to a set of policies that discriminated against agriculture on the one hand and subsidized it on the other. This experience has led some observers to characterize development policy as band-aid economics.

\section{Agricultural development}

The perceived role of agriculture shifted dramatically as development thinking changed. In the dualistic view, agriculture could be squeezed, even as industry was protected to accelerate the transfer of surplus labor to the modern sector. This was resisted by proponents of agricultural development [17-19] who pointed out that levels-of-living would not be raised by impoverishing those whose livelihoods depend on agriculture. Jorgenson [24] showed how neoclassical forces could account for the relatively rapid increase in manufacturing employment. Johnston and Mellor [20-23] went further, describing how agricultural investments stimulate the larger economy through "pro-poor" linkages - lower food prices, higher employment and real wages, and a simultaneous Engel-induced demand for non-agricultural products and an economic surplus with which to fund their production.
During the interventionist 70s, it was natural to seek favorable linkages by subsidies and market interference in the name of market failure and Integrated Rural Development. The subsidies were largely delivered through line agencies with little or no accountability [12] and discouraged the emergence of spontaneous, unsubsidized institutions [25]. Confiscatory land reform and a whole range of input subsidies both blunted incentives and provided opportunities for rent-seeking by coalitions of political and commercial elites. Infrastructure projects were characterized by huge discrepancies between project design and realization [26]. Growth in agriculture progressed nonetheless, aided in part by new technologies and growth in factor productivity [27]. One limitation of the Johnston-Mellor model was its implicit assumption of a closed economy. As the 80 s brought new enthusiasm for trade-led growth, agricultural development thinking became more outward oriented [28-30]. Despite this, liberalization of agriculture lagged behind that of manufacturing [27]. Rising per capita incomes, increased capital-labor ratios, and agriculture's increasing concentration and commercialization all contributed to the resiliency of agricultural protection [31].

Turning the participatory development movement of the 90 s and beyond on rural issues has resulted in community driven development [12]. CDD is an approach that aims to "empower communities and local governments with resources and the authority to take control of their development" [32]. The four core features of $C D D$ are real participation, improving accountability, technical soundness, and sustainability. Real participation involves stakeholder analysis to include citizens in every level of decision-making. Development choices are analyzed with a full representation of interests and under a hard budget constraint. Communities have control over resources, program design, selection, and implementation. Improved accountability shifts the emphasis to horizontal accountability, wherein community members are empowered to take corrective actions against errant peers. Technical soundness implies using methods that have been field-tested in a variety of social and environmental regions. Fiscal, asset, environmental, and social sustainability are also called for. The promise of CDD is its recognition that political feasibility is essential for successful policy reform. Before widespread adoption it must become undergirded by the principles of institutional design and synthesized from systematic case studies.

\section{Persistent policy failures}

There is a family resemblance between the policy failures in the interventionist 70 s and the 
new informational 90 s. Interventions in the 70 s were based on the diagnosis of market failure and the prescription of Pigouvian cures. This method commits a Nirvana Fallacy by failing to engage in the comparative institutions necessary to balance prospects for improved resource allocation with unintended consequences and implementation failures [33]. In post-modern interventionism, market failure derives from misallocations in equilibrium, albeit without considering voluntary mechanisms of governance and multilateral cooperation. Like the old fallacy, the new nirvanaism suffers from misplaced exogeneity. The tendency to socially engineer reforms instead of facilitating cooperation persists. Just as the old structure, conduct, performance paradigm was replaced by contestable market theory and other innovations, the prospects for improved empirical work on developing agriculture await the development of an appropriate structural model wherein farm organization, specialization between family and hired labor, and choice of contracts across tasks and economic environment are understood as parts of an endogenous whole. Some of these themes are developed in specific contexts below.

\section{Policies and programs}

\section{Behavior: Risk and crop insurance}

Before Schultz's Transforming Traditional Agriculture [34] it was widely believed that peasant farmers were traditional-bound, ignorant, lazy and consequently backward. Accordingly, their behavior was widely thought to be beyond the non describable by the scope of conventional models of economic rationality. Schultz shattered that belief, showing that poverty among peasant farmers derived from limited resources, including human capital, and from a stagnant technology, most from sloth or decision-making failures. Just as Schultz's book was catching on in the late 60 's, however, new high yielding varieties (HYV's) of rice and wheat were becoming available in Asia and Latin America. The new seeds were dubbed "miracle varieties" and rapid early adoption was called a "green revolution".

By the end of the 1960's, however, it became apparent that the HYV's were not meeting expectations. The forecasted doubling and tripling of yields was rarely realized. The rate of increase in the incidence of adoption slowed down much earlier than expected and when varietal adoption did take place, farmers generally "failed" to adopt the packages of inputs and cultural practices that were recommended by the international and national research and extension services.

Agricultural development professionals faced a quandary. On the one hand, they had recently been converted to the view that farmers were economically rational. On the other hand, farmers failed to adopt production techniques that were thought far superior to traditional practices. The agricultural development texts of the day $[18,35]$ suggested a resolution to the apparent paradox. Farmers were rational but, due to incomes in the proximity of subsistence levels-of-living, were said to be highly risk averse. New varieties and the associated packages of recommended practices were assumed to be much more risky than traditional practices, which were thought to perform better under adverse circumstances. In summary, low-income farmers are risk-averse (RA), modern technology is more risky, and low-income farmers will therefore underinvest (UI) in modernization - RAUI for short. Empirical evidence for the RAUI hypothesis is said to be mixed. Roumasset [36] and Walker [37] reject the hypothesis, but a number of other studies find supporting evidence for the role of risk in cropping decisions, varietal adoption, and fertilizer use [38]. Anderson and Hazell [38] provide a number of reasons why RAUI has not been more regularly confirmed. First, the modern technology, while more variable, may stochastically dominate the more traditional technology. Second, output variability is often negatively correlated with price fluctuations. Third, risk-reducing strategies, including both diversification and risk sharing $[39,40]$ and fourth, risk-coping strategies for consumptionsmoothing [41-43].

What has not been definitively determined is the extent to which methodology is responsible for the mixed results. In particular, failure to fully specify to consequences different choices may result in risk proxying for omitted non-linearities. This can be avoided by a complete specification of payoffs for each production technique under consideration for each state of the world. This makes it possible for the analyst to compute optimal behavior under the competing objectives. Only then is it possible to make a meaningful comparison, for a sample of farmers, between actual behavior and predicted behavior under each model.

The RAUl hypothesis was also a convenient rationale for subsidizing crop insurance. The prevailing orientation of agricultural development planning during the $60 \mathrm{~s}$ and $70 \mathrm{~s}$ had been largely shaped (or was at least reflected in) by Mosher's Getting Agriculture Moving [17]. The idea was to locate the bottleneck to development and design government in intervention to remove it. The RAUI hypothesis fit into this thinking perfectly. Risk aversion was the culprit, and crop insurance appeared to be the natural tool to break the constraint.

By the early 1980's, however, it had become apparent that crop insurance was not a particu- larly effective instrument for promoting agricultural development, in addition, was very costly. A new consensus emerged that crop insurance was good in theory but too costly in practice [44-46].

High administrative costs were thought, by new consensus authors, to be due to bureaucratic inefficiency and to the large number of small and sometimes geographically dispersed forms in developing countries and to moral hazard and adverse selection. Adverse selection was thought to require costly actuarial techniques to distinguish between high and low risk farms. Moral hazard was similarly thought to require costly monitoring to ensure proper precautions were taken, e.g., the judicious application of pesticides. This view holds out the hope that if only new administrative approaches can be found, crop insurance can yet be made into a viable tool of agricultural development. I believe, rather, that crop insurance is bad in practice precisely because it is bad in theory, and the time has come to give it up and turn to more promising approaches to agricultural development.

As explain by Quiggin [47] crop insurance causes positive negligence as well as negative negligence. Negative negligence is the tendency, even for a risk neutral farmer, to overuse risk-reducing inputs such as pesticide. Positive negligence is the tendency to overuse inputs that are yield increasing in the good state and yield decreasing in the bad state, e.g. fertilizer in drought prone areas. For a risk averter, the input effects of crop insurance result from a combination of the moral hazard effect and the risk-bearing effect. For inputs with a negative marginal product in the bad state (and a high enough marginal product in the good state to warrant use) crop insurance will lower the riskbearing cost of the input, i.e., the risk-bearing effect on input use is positive. On the other hand, if the marginal product in the bad state is positive enough to decrease risk, crop insurance will decrease the use of that input. In these two cases, crop insurance exacerbates positive and negative negligence. Clearly, crop insurance may therefore produce negative benefits. Subsidized crop insurance will also partially displace risk-reducing and risk-coping strategies causing additional excess burden.

Another fallacy in the conventional view of crop insurance is that utility functions in current period income or wealth are taken as given. As shown in Roumasset [48], however, such functions are inherently indirect and depend on the structure of assets, liabilities and transaction costs. Making subsidized crop insurance available or mandating insurance will change the utility function, in particular truncating the lower end. Among other things the indemnities obfuscate idiosyncratic transaction 
costs that the efficient decision maker takes into account. In short, the insurance promotes getting-the-incentives wrong.

\section{Marketing, parastatals, and price policy}

Rashid et al. [49] review the original motivation of parastatals and conclude that their dismantling should be accelerated. Their case against parastatals is actually somewhat conservative. The traditional case for parastatals presumes that governments can stabilize prices. Williams and Wright [50] show, however, that trying to insulate domestic markets from international price fluctuations is counterproductive. Indeed the best means of stabilizing prices involves using international markets to stabilize domestic prices. Evidence to the effect that domestic prices vary less than international prices should not be construed as implying that governments have succeeded in stabilization. First, international markets are residual markets implying greater variability and that variability in the two markets are non-commensurate (Siamwalla). Second, data on "domestic prices" already contains a huge amount of averaging/smoothing. Third, such evidence may be selective. Some authors maintain that domestic prices are not more stable. Fourth, there is a non-observed counterfactual. We don't know how stable domestic prices would have been in the absence of government controls. Moreover, price stabilization may decrease economic welfare. Some argue that stabilization is a political necessity, but it appears that what is political is fooling some of the people into believing that government is in fact stabilizing when they are in fact extracting rents [51].

Timmer [52] makes a compelling case that border prices do not confer correct signals for agricultural development. Given the pro-poor and development linkages of agricultural development (lower food prices and higher demand for labor both lower poverty; higher rural incomes promote the demand for manufactures), increased incentives for agricultural growth may be warranted. This does not imply that agricultural price protection is warranted, however. Nor does agricultural protection in the developed economies, even though it artificially lowers border prices. Moreover, as discussed above in the context of the East Asian Miracle, industrialization is commonly assumed to confer greater external economies than agricultural growth. Most importantly, subsidized prices, especially when administered via monopolized import controls, fragment the economy and pull entrepreneurial resources into rent-seeking instead of productive innovation [53].

\section{Land and labor markets}

The efficiency case for land reform has traditionally been based on two planks - the relative inefficiency of large, commercial farms in the utilization of labor, and the inefficiency of tenancy, especially share tenancy. A number of studies have suggested that hired labor is inefficient relative to family labor $[54,55]$.

Utilizing family labor economizes on recruiting and supervision costs, the latter because family labor standsto lose from both quality and effort shirking. These labor market imperfections result in the productivesuperiority of family farms [56] and to the characterization of hired labor as inefficient [57]. In contrast, Benjamin [58] finds that hired labor is neither significantly more nor lessproductive than family labor. The empirical case for inefficiency rests largely on the notorious inverse relationship between sizeand productivity [59]. Recent evidence is mixed, however. Some studies confirm theinverse relationship $[60,61]$. Others fail to reject constant returns to scale $[62,63]$.

But the inverse relationship is also consistent with the efficient allocation and employment of labor. First-best efficiency predicts that landlords will equate the marginal product of labor across diverse landqualities by adjusting the size of family farms thus leading to the observation of higher per hectare yields onsmaller farms [64]. Indeed, Benjamin [65] shows that the inverserelationship is at least partly due to the bias induced by omitting land quality from the regressions [36]. Deininger asserts, however, that the inverse relationship persists even after controlling for land quality withproxies such as land value. But land value is not an accurate indicator of land's potential agriculturalproductivity, nor is distance-to-market and other proxies. Lacking a perfect measure, one cannot confidentlyreject the hypothesis that the inverse relationship is due to land quality nor conclude that the relationshipimplies higher productivity of small-farm labor.

A second-best efficiency explanation for the inverse relationship is that the shadow price of labor forfarm households that hire labor at the margin is higher than that for households who supply all of the farmlabor, especially so for households who supply labor to other farms as well as their own [66]. To theextent that the inverse relationship is sourced in this cause, no inefficiency is indicated. In the secondbestequilibrium, shadow prices vary over space, time, and economic agents. Using a first-best standard ofefficiency risks drawing policy implications that have efficiencydecreasing consequences. Future documentation of the inverse relationship should distinguish between family and commercialfarms. Feder [67], Eswaran and Kotwal [68] and Carter and Wiebe [69] and Deininger [56] discuss the possibility that the inverse relationship could reverse for larger farms, noting that that theirdisadvantages in the labor market could be outweighed by their advantages in credit and other markets. Indeed, Uy [70] finds an inverse relationship on family farms but a positive relationship betweenproductivity and farm size on commercial farms. Likewise, in the new supermarket economics [71] dedicated wholesalers coordinate specific farmers with specific retailers with appropriateprocurement, quality, safety, and timing standards and thereby confer transaction cost advantages on largefarms. The currently populist World Bank displays a curious schizophrenia here. They are quick to legitimizebreaking up large farms because small farms allegedly economize on the transaction costs of hiring labor. But when faced with evidence that large farms have transaction cost advantages in credit and marketing, theycall for cooperatives to appropriate those advantages, despite theoretical and empirical obstacles.

For the empirical literature on hired labor to progress, two improvements are needed. First, thedifferent types of transaction costs must be distinguished. Transaction costs have been defined by Nobel Laureate Kenneth Arrow as costs of running the economic system and are the economic equivalent of frictionin physical systems [72]. The primary category of transaction costs is contracting costs, including the costs of participant-selection, negotiation, and enforcement. Lower costs of transportation, communication and institutional innovations that lower enforcement costs facilitate falling unit transactioncosts per worker. But as intensification and specialization increase, for example, as the number of workers perhectare rises, transaction expenditures increase, even as unit transaction costs fall. Making this distinction isessential for future empirical work.

The second needed improvement is to recognize that the choice of hired vs. family labor isendogenous and that the two kinds of labor will naturally differ in both tasks and skills. In the simple version of the wedge model $[73,74]$ household and hired labor are assumed to beperfect substitutes, and labor is hired because of the rising opportunity cost of household labor. An additionalreason for hiring labor is that it facilitates specialization such as teams of workers that move from farm-to-farm doing the same task [75]. On the prototypical farm in which both family and hired labor are employed, economics implies that there will be a non-random division of tasks between family and hired laboraccording to the comparative advantages of each.

Substantial interventionist ink has also been spilled asserting the inefficiency of share tenancy. The old interventionist view was based 
on the so-called Marshallian model, which was perfect Pigouvianism, albeit before Pigou ${ }^{3}$. According to Marshall's famous footnote, the rational tenant equates his marginal opportunity cost of labor with only his share of the marginal product. This conclusion has been used to justify the other primary plank of land reform - the banning of share tenancy. Cheung debunked this view, observing that the Marshallian model could hardly be an equilibrium contractual solution inasmuch as the landlord and tenant could renegotiate about the share and amount of output or inputs that must be provided or used, thereby making both parties better off.

Stiglitz proposed a principal-agency model wherein sharecropping is viewed as a pairwiseefficient means of incentivizing labor, relative to wage contracts, without the cost of riskbearing that would be imposed under rent contracts. He thus resurrected Marshallian ineffieciency and the proposition that share tenancy should be outlawed. Indeed Stiglitz [9] has often used the institution of share tenancy to exemplify how economic organization can be in equilibrium but massively inefficient, asserting that a landlord's share of $1 / 2$ would have the same disincentive effects as a $50 \%$ income tax. The model has had a long and successful run in agricultural development circles. Hayami and Otsuka (1993) conclude that the risk-aversion vs. moral hazard model indeed "justifies the existence of share tenancy in the theoretically most consistent manner..." and econometric studies have concluded that the model is empirically sound.

As is the case with the literature on the inefficiency of large farms and hired labor, however, this conclusion is premature. First, the canonical model does not imply, as originally claimed that the optimal share, $\beta$, varies positively with the tenant's degree of risk aversion. Risk aversion also blunts the tenant's incentive to shirk. Second, the model is incapable of explaining the empirical distributions of tenant shares, which cluster around of $50 \%$, with a smaller cluster around $2 / 3^{4}$ But the larger problem is that the theory fails to recognize the nature of share tenancy, a typically long-term contractual arrangement for bringing management together with land and that facilitates the tenant's learning-by-doing about production decisions. Share tenants themselves hire sub-

\footnotetext{
${ }^{3}$ It is easy to show that Marshallian underemployment is readily cured by a Pigouvian labor subsidy.

${ }^{4}$ Deweaver and Roumasset [7], show that, for parameters representative of the Philippine case, the model predicts that optimal tenant's share declines from one to $80 \%$ as the tenant goes from risk neutrality to moderate risk aversion and increases back to one as risk aversion increases further.
}

stantial amounts of labor, especially for the more arduous and routine tasks. On the other hand, share contracting is a popular labor contract for specific tasks. Indeed, share tenants often hire casual workers on a share basis to do harvesting, weeding, and transplanting. These rationales for land reform fail to acknowledge the complexity of economic cooperation. The principle of comparative advantage implies that different characteristics of land and landowners will call for different intensities and composition of inputs and organizational forms with unlimited differences in architecture. Judging the relative efficiency of different organizational forms commits the most fundamental fallacy in economics - judging performance without understanding the nature and causes of the phenomenon of interest ${ }^{5}$. Prescribing policy reforms based on the premise that politicians, bureaucrats, and academics can socially-engineer institutions superior to those shaped, tested, and improved in the crucible of evolution is a recipe for government failure.

For example, land reform in the Philippines outlawed share tenancy. As a result, land reform beneficiaries hired permanent workers who were paid a fixed amount for the season. Hayami and Otsuka conclude that this has been an inferior substitute for share tenancy. Another Philippine example concerns the failure to consider properly base landlord compensation on quality. By basing compensation on the principle that $25 \%$ of yield is a fair rent, reform confiscates value from owners of good and average farms but actually over-rewards owners of poor-quality land [64]. As a result, friends and relatives of poor-quality landowners submit bogus claims that they have been working the land as tenants so that the landlord receives more than the land is worth (and landownership remains in the family).

\section{Rural credit}

Beginning in the 1950s and 60s, and expanding rapidly in the 70 's, many governments in Asia and elsewhere in the developing world concluded that small farmers lacked access to adequate capital and established directed credit policies. These programs typically provided subsidized credit to agricultural and rural banks, instructing the banks to lend to an agricultural and rural clientele without exceeding controlled interest rates. These programs performed poorly. Loans were disproportionately given to large commercial clients, and there

\footnotetext{
${ }^{5}$ In Coasean terms, this is known as blackboard economics.
}

were high default rates $[76]^{6}$. The authors conclude that their study supports the hypothesis of Shaw [78] and McKinnon [79] that "repressed financial systems constrain economic growth." The conclusions of the "Ohio School" may be too extreme, however. Stiglitz and Uy [80] conclude that modest financial restraint was a key ingredient in the East Asian Miracle. Making financial markets work better and improve resource allocation without picking winners e.g. through savings promotion, regulations to improve solvency, creation of financial-market institutions (e.g. bond and equity markets), and broad-based regulations that direct increased credit to the corporate relative to the household sector. The last policy is said to promote external economies, especially technological and marketing spillovers. Promoting slightly lower interest rates is said to decrease savings by households but more than compensates by increasing savings among corporations.

As the directed credit program waned, due to low repayment rates and inability of rural banks to survive without large infusions of new subsidies, focus turned to the micro credit cooperative approach where "peer monitoring" substitutes for collateral [81]. Morduch concludes however that while micro credit institutions are more profitable than the directed credit approach, they are typically not sustainable without administrative subsidies. In order to analyze the consequences of credit market policies, we need to model the provision of credit. The first challenge is to explain the co-existence of formal and informal credit. Hoff-Stiglitz [82] assume that formal lenders have lower opportunity costs of loanable funds but that informal lenders have better information about individual borrowers. Formal lenders also have a comparative advantage in utilizing formal enforcement institutions, while informal lenders rely on repeated exchange and reputation effects for enforcement [83]. Hoff-Stiglitz provide a model in which formal sector subsidies allow some borrowers to enter or expand in the informal market. Said expansion results in loans to less reliable and higher cost borrowers resulting in a higher interest rate. Ghosh et al. [84] obtain a similar result from a model with differential bargaining power of lenders relative to borrowers, where

\footnotetext{
${ }^{6}$ As early as 1972, the US Agency for International Development Spring Review for Small Farmer Credit found that "the major increases that occurred in formal finance have mainly gone to larger farmers." Similarly, Gonzalez-Vega [77] found that subsidized interest rates actually benefit the rich. Meyer and Nagarajan [76] conclude that three decades of rapid changes and government interventions have left "a fragile financial system with limited outreach."
} 
relationships are exclusive and interest rates are uniform.

Assuming the law of one price in credit markets abstracts from the essence of credit, however. Credit is not wheat. The nature of the service varies across borrowers and the terms of the credit contract depend on the amount of the loan, the asset-liability position of the borrower, and other borrower characteristics. Bose [85] provides a promising extension. He assumes that there are two types of informal lenders - the informed and the uninformed and replaces the assumption of one price per market with the assumption that lenders offer their clients a menu of loan sizes and interest rates. When the government subsidizes credit, the perfectly informed lender offering lower interest rates increases his lending activity, choosing to lend only to reliable clients. The uninformed lender then faces a higher proportion of risky clients and lower expected profits, and must raise his rates and ration credit. This allows the informed lender to increase his interest rates.

These models represent market failure from information distortions augmented by these subsidies. Policy implications are to eschew such subsidies, to improve information networks and to advance complementary markets both to decrease costs and to increase the bargaining power of borrowers. The directed credit approach and the new informational approach can combined by acknowledging government failure. Directed credit policies have artificially fragmented capital markets. Further subsidies will worsen allocative efficiency unless severe interest rate controls and sectoral direction is relaxed. By understanding the evolution of credit market deepening where it has been successful, insights into a facilitation approach can be attained.

\section{Research and extension}

Birkhaeuser et al. [86] review 9 studies published between 1973 and 1988 on the rate of return to extension. These estimates range from negative to $115 \%$. Evenson [87] reviews another 6 studies conducted between 1973 and 1989. Between the two reviews, a total of 26 linear estimates of returns to extensions were reported. Of these 26 estimates, only 11 were significant at the $90 \%$ confidence level. Of all of these, none found extensions to increase total crop value by more than $27 \%$. Owens et al. [88] note, however, that these estimates tend to be biased upwards due to endogenous program placement and two-way selection bias (agent selects farmer and/or farmer selects agent). Using productivity and farmer data (e.g., crop production and yields, revenues, land used in agricultural production, labor input, levels of education, rainfall, land quality, slope, soil type, and distance to market) from rural Zimbabwe, Owens et al. find that agricultural extensions (as defined as regular visits once or twice per year) raise the value of crop production by $15 \%$. Inasmuch as these corrections cannot entirely control for withinlocation quality variation and differences in farmer characteristics some upward bias may remain however. What is clear is that the returns to extension can be substantial and that sometimes extension fails to deliver a positive return. Accordingly research needs to shift from the question of how much extension to the question of how extension services should be delivered. Research on farmer behavior relative to recommended practices affords some tentative conjectures. First, top-down extension that attempts to coerce, cajole, or subsidize farmers into adopting "accepted practices" is risky business. Extension agencies are typically unable to tailor recommended practices in accordance with economic efficiency given the enormous diversity in agro-climatic, economic, and institutional environments. Instead, extension should offer farmers a menu of promising practices that may be suitable for their conditions and simultaneously communicate those conditions and farmer concerns back to the research establishment. Second, measures of extension agent performance are needed such that suitable agent incentives can be designed and implemented. Until this happens, horizontal and vertical accountability in extension will remain buzzwords.

\section{Water resource management}

The enthusiasm for growth with equity generated during the 1970s brought with it a rapid increase in publicly-financed irrigation. As documented, e.g. by Repetto [26], investment performance was far less than its potential. Project selection and design as well as operation and maintenance were compromised by rent-seeking. The Washington-Consensusprescribed full cost recovery was a poorlyconceived and infeasible substitute, however. The correct antidote to rent-seeking is benefit taxation, but direct beneficiaries should only be required to pay up to the percentage of direct out of total benefits. In addition, water provision should be in accordance with principles of reciprocal accountability and appropriate centralization of function. Project design as well as operation and maintenance should be devolved to the local water authority, provision of a menu of technology provided by the national water authority, and division of finance between direct and indirect beneficiaries coordinated by the treasury of finance ministry. These principles are illustrated below.

\section{Synthesis and new directions}

In the not-so-distant past, land reform was justified by two stylized facts. The first was the inverse relationship between yield per hectare and farm size, said to be caused by dualism in agricultural labor markets. The second was the mere existence of share tenancy, thought to be inefficient and exploitative. These claims are now recognized as founded on ad hoc theorizing, and more fundamental explanations of the stylized facts have been recognized [66]. In the "new dualism" a more market-friendly, albeit still interventionist, land reform is justified by the claim that commercial farms are inefficient, due to the inefficiency of hired labor [56] along with a belief that asset redistribution is an effective instrument of poverty reduction?.

The tendency to leap to policy implications from a single explanation of a stylized fact perseveres. Not only do explanations need to be more complete in the sense described, but multiple explanations, with potentially different implications, should be entertained. Politicians, and many academics, have the incurable disease of top-downism. As recognized by Adam Smith, they are forever designing rules, regulations, and institutions to be coercively imposed on the economy ${ }^{8}$. For example, despite decades of failed land reform legislation that have resulted in untold waste and injustice, land reform efforts continue to this day. The palliative for top-down tinkering with institutional design is an understanding of institutional choice and evolution. More specifically, we need a theory of how agricultural

\footnotetext{
${ }^{7}$ The element of confiscation is not necessary and indeed was not advocated in Deininger's earlier articulation of market-friendly land reform. To the extent that land reform is a political necessity, inefficiency can be minimized by rendering the division of large farms voluntary. This can be done by making property taxes progressive according to farm size/value. 8 "The man of system, on the contrary, is apt to be very wise in his own conceit; and is often so enamoured with the supposed beauty of his own ideal plan of government, that he cannot suffer the smallest deviation from any part of it. He goes on to establish it completely and in all its parts, without any regard either to the great interests, or to the strong prejudices which may oppose it. He seems to imagine that he can arrange the different pieces of a great society with as much ease as the hand arranges the different pieces on a chessboard. He does not consider that the pieces upon the chess-board have no other principle of motion besides that which the hand impresses upon them; but that, in the great chess-board of human society, every single piece has a principle of motion of its own, altogether different from that which the legislature might chuse to impress upon it." - Adam Smith Theory of Moral Sentiments,
} VI.ii.2.17. 
organization evolves from a self-sufficient peasant economy to a more specialized and intensive market economy. As also envisioned by Adam Smith, the division of labor affords a window into market development generally. Specialization is limited by the size of the potential market, and the size of the market is limited by population, incomes, and transaction costs. On the other hand, a healthy respect for the role of efficiency in institutional change should not lead to one to ignore the conventional role of government in the provision/internalization of public goods/externalities and the less conventional role of facilitating economic cooperation more generally. In particular, investing in agricultural research and legal as well as physical infrastructure, will stimulate the coevolution of the division of labor and the corresponding institutional change. As specialization proceeds, more and more complex patterns of coordination are facilitated. In Reardon et. al.'s [71] supermarket metaphor, for example, farmers are increasingly linked to specific retailers by means of complex chains that transform farm products over space, time, and form; thereby replacing the cumbersome and costly method of indirect coordination via inventories. The transaction sector that produces such transformation actually grows, even as the per-unit costs of coordination fall [89]. The agricultural development that ensues from this approach is likely to have a high growth elasticity of poverty reduction [90]. Not only does the facilitation strategy generate the traditional pro-poor linkages associated with lower food prices and higher demand for labor, but it aids workers whose wages are net of lower unit transaction costs as well as small farmers who benefit from falling transaction costs being subtracted from their sales and added to their purchases. The alternative of central design may actually fragment economic connectivity and stagnate efficiencyenhancing evolution.

When Paul Krugman innovated the new international economics, he observed that it did not obviate the neoclassical model but supplemented it. In the same way, NIE does not contradict previous lessons from economic theory, such as the aforementioned linkages. Rather it can help not only with the new issues of market facilitation, but also with institutional design regarding incentive structures and management of potentially high-payoff investments such as agricultural research.

One lesson from the history of thought that bears learning (lest one repeat it) is that the fads and fancies of development strategy have shifted one to another without adequate appreciation of the successes and failures of previous stages. In particular, investments in agricultural infrastructure and research were often successful, albeit their potential was not fully realized due to organizational problems in their implementation and remaining policy distortions.

The role of government is to stop fragmenting the economy through subsidies and constraints, push agriculture, e.g. through research and well-designed investments in irrigation, and to facilitate cooperation. To understand how to proceed with the third mission, further positive research is warranted. For example, how did capital markets evolve in different countries from fragmented institutions to integrated, complex, and deep markets? How did the evolution of specialization evolve and how was it related to the movement of factor prices and productivity? These questions call for explorations in many countries over several centuries.

\section{REFERENCES}

1. INTERNATIONAL FUND FOR AGRICULTURAL DEVELOPMENT (IFAD). Global Poverty Report for 2001. 2001.

2. POPPER K. The Open Society and its Enemies. London: Routledge, 1945.

3. LEWIS AW. Economic Development with Unlimited Supplies of Labor. The Manchester School 1954; 22(2): 139-91.

4. RANIS G, FEI JCH A. Theory of Economic Development. Am Econ Rev 1961; 51: 533-65.

5. GREENWALD B, STIGLITZ J. Externalities in Economies with Imperfect Information and Incomplete Markets. Q J Econ 1986; 101(2): 229-64.

6. STIGLITZ J. Post Washington Consensus Consensus. IPD WP, Columbia University, 2004.

7. DEWEAVER M, ROUMASSET J. Risk aversion as effort incentive: A correction and prima-facie test of the canonical theory of share tenancy. Econ Bull 2002; 15(4): 1-16.

8. ROUMASSET J, BARR S, eds. The Economics of Cooperation: East Asian Development and the Case for Pro-Market Intervention. Boulder: Westview Press, 1992.

9. STIGLITZ I. Globalization and its Discontents. New York: W. W. Norton and Company, 2002.

10. YANG XN. YK Specialization and economic organization: A new classical microeconomic framework. New York: Elsevier Science, 1993.

11. SACHS I, YANGX. Development Economics: Inframarginal versus Marginal Analysis. MA: Blackwell, 2000.

12. BINSWANGER H. Agricultural and Rural Development. Nigeria Policy Dialogue, (available at http://www2. gsb. columbia. edu/ipd/hpb_ nigeria.pdf. ). 2004
13. STIGLITZ J. Whither Socialism? Cambridge, MA: MIT Press, 1995.

14. USAID. Foreign Aid in the National Interest: Promoting Freedom. Security, and Opportunity, 2002.

15. SACHS J. The End of Poverty: Economic Possibilities for Our Time. Penguin Press, 2005.

16. EASTERLY W. Review of Sachs, The End of Poverty: Economic Possibilities for Our Time. Washington Post, March 13, 2005 http://www. washingtonpost. com/wpdyn/articles/A25562- 2005Mar10. html.

17. MOSHER AT. Getting Agriculture Moving: Essentials for Development and Modernization. New York: Praeger, 1966

18. MELLOR JW. The Economics of Agricultural Development. Ithaca, New York: Cornell University Press. , 1966.

19. MYRDAL G. Asian Drama: An Inquiry into the Poverty of Nations. New York: Pantheon, 1968.

20. JOHNSTON BF, MELLOR JW. The Role of Agriculture in Economic Development. Am Econ Rev 1961; 51(4): 566-93.

21. MELLOR JW. Agriculture on the road to industrialization. In: Lewis JP, Valeriana K, eds. Development Strategies Reconsidered. New Brunswick, N): Transaction Books, 1986; (Reprinted in Eicher, Carl K. and John M. Staatz, Agricultural Development in the Third World, 3rd Edition. Johns Hopkins University Press, Baltimore).

22. MELLOR JW, JOHNSTON BF. The World Food Equation: Interrelations Among Development, Employment, and Food Consumption. / Econ Lit 1984; 22: 531-74.

23. MELLOR JW. Agriculture on the Road to Industrialization. Baltimore: Johns Hopkins University Press, 1995

24. JORGENSON DG. The development of a dual economy. Econ / 1961; 71: 309-34.

25. ROSEGRANT M, HAZELL P. Transforming the Rural Asian Economy: The Unfinished Revolution. Oxford, UK: Oxford University Press/ International Food Policy Research Institute, 2000.

26. REPETTO R. Skimming the Water: Rent Seeking and the Performance of Public Irrigations. Washington DC: World Resources Institute, 1986.

27. FEDERICO G. Feeding the World. Princeton U. Press, 2005.

28. CLARETE R, ROUMASSET I. A Shoven-Whalley Model of a Small-Open Economy: An Illustration with Philippine Tariffs. J Public Econ 1987; 32: 247-61.

29. KRUEGER A, SCHIFF M, VALDÉS A. Agricultural Incentives in Developing Countries: Measuring the Effect of Sectoral and Economywide Policies. World Bank Econ Rev 1988; 2: 255-72. 
30. GARDNER B. Policy Reform in Agriculture: An Assessment of the Results in Eight Countries. Department of Agricultural and Resource Economics, University of Maryland, 1996.

31. BalisaCAN A, ROUMASSET J. Public Choice of Economic Policy: The Growth of Agricultural Protection. Weltwirtschaftliches Archives, 1987.

32. BINSWANGER H, ATYARS. Scaling Up Community-Driven Development. World Bank Policy Research Working Paper, 2003; (3039).

33. DEMSETZH. Information and Efficiency: Another Viewpoint. J Law Econ 1969; 10: 1-21.

34. SCHULTZ TW. Transforming Traditional Agriculture. New Haven: Yale University Press. , 1964.

35. WHARTON CR. The Green Revolution: Cornucopia or Pandora's Box. Foreign Aff 1969; 47: 464-76.

36. ROUMASSET J. Rice and Risk: Decision-Making among Low-Income Farmers in Theory and Practice. Amsterdam: North-Holland Publishing Co. , 1976.

37. WALKER T. Decision Making by Farmers and by the National Agricultural Research Program on the Adoption and Development of Maize Varieties in El Salvador. PhD thesis, Stanford Food Research Institute, Stanford, California, 1980.

38. ANDERSON JR, HAZELL PBR. Risk considerations in the design and transfer of agricultural technology. In: Anderson JR, ed. Agricultura Technology: Policy Issues for the International. 1994.

39. WALKER TS, JODHA NS. How small farmers adapt to risk. In: Hazell P, Pomareda C, Valdes A, eds. Crop Insurance for Agricultural Development: Issues and Experience. Baltimore, USA: John Hopkins University Press, 1986.

40. WALKER TS. Yield and Household Income Variability in India's Semi Arid Tropics. In: Anderson JR, Hazell PBR, eds. Variability in Grain Yields: Implications for Agricultural research and Policy in Developing Countries. The Johns Hopkins University Press. , 1989.

41. DEATON A. On Risk, Insurance and Intra-Village Consumption Smoothing. Research Program in Development Studies. Princeton University, N. J. , 1990.

42. PAXSON CH. Borrowing constraints and portfolio choice. Q J Econ 1990; 105(2): 535-43.

43. TOWNSEND RM. Risk and Insurance in Village India. Econometrica 1994; 62(3): 539-91.

44. HAZELL PBR. The Appropriate Role of Agricultural Insurance in Developing Countries. I Int Dev 1992; 4(6): 567-81.

45. HAZELL P, POMAREDA C, VALDÉS A, eds. Crop Insurance for Agricultural Development Issues and Experience. Baltimore: Johns Hopkins University Press, 1986.

46. NELSON CH, LOEHMAN ET. Further Towards a Theory of Agricultural Insurance. Am J Agricult Econom 1987; 69: 523-31.
47. QUIGGIN J. Some Observations on Insurance, Bankruptcy and Input Demand. I Economic Behaviour Organiz 1992; 18: 101-10.

48. ROUMASSET J. Risk aversion, agricultural development and the indirect utility function. In 11979.

49. RASHID S, CUMMINGS R, GULATI A. Grain Marketing Parastatals in Asia: Why Do They Have to Change Now? IFPRI/MTID Discussion Paper No. 80. 2005.

50. WILLIAMS JC, WRIGHT BD. Storage and Com modity Markets. Cambridge University Press. , 1991.

51. ROUMASSET J. Agricultural parastatals and propoor economic growth. International Workshop on Agribusiness: From Parastatals to Private Trade - Why, When and How? 2003; 15-6 December. New Delhi, India.

52. TIMMER CP. Food Security and Rice Price Policy in Indonesia: The Economics and Politics of the Food Price Dilemma. Indonesian Food Policy Program, Working Paper 2002; No. 14.

53. ROUMASSET J. The Microeconomics of Agricultural Development in the Philippines. University of Hawaii, Department of Economics Working Paper \# 02-10, 2002.

54. BINSWANGER H, ROZENWEIG MR. Behavioral and material determinants of production relations in agriculture. / Dev Stud 1986; 22: 50339.

55. BINSWANGER H, DEININGER K, FEDER G. Power, distortions, revolt and reform in agricultural land relations. In: Behrman J, Srinivasan TN, eds. Handbook of development economics. Vol. II. Amsterdam, New York and Oxford: Elsevier Science, North-Holland Publishing Co. , 1995.

56. DEININGER K. In: Land policies for growth and poverty reduction. World Bank Policy Research Report. World Bank and Oxford University Press, 2003: 84.

57. OTSUKAK. Land markets. In: Evenson R, Pingali P, Schultz TP, eds. Handbook of Agricultural Economics: Agricultural Development: Farmers, Farm Production, and Farm Markets. Volume 3A. Amsterdam: Elsevier Science, NorthHolland Publishing Co. , 2005.

58. BENIAMIN D. Household composition, labor markets and labor demand: testing for separation in agricultural household models. Econometrica 1992; 60: 287-322.

59. BERRY A, CLINE W. Agrarian structure and productivity in developing countries. Baltimore: United States of America, Johns Hopkins University Press, 1979.

60. BURGESS R. Land and welfare: Theory and evidence from China. Working paper. London School of Economics, 2001.

61. UDRY C. Gender, Agricultural Production, and the Theory of the Household. J Polit Econ 1996; 104(5): 1010-46.
62. DOW GK, PUTTERMAN L. Why Capital Suppliers (Usually) Hire Workers: What We Know and What We Need to Know. J Economic Behavior \& Organiz 2000; 43: 319-36.

63. WAN GH, CHEUNG E. Effects of land fragmentation and returns to scale in Chinese farming sector. Appl Econ 2001; 33(2): 183-94.

64. ROUMASSET J, JAMES W. Explaining variations in share contracts: land quality, population pressure and technological change. Australian Journal of Agricultural Economics 1979; 23(2): 116-27.

65. BENJAMIN D. Can unobserved land quality explain the inverse productivity relationship? J Dev Econ 1995; 46(1): 51-84.

66. SAH RK. Size, supervision and patterns of labor transactions. I Philippine Development 1986; 13(1, 2). (also available at http://dirp4. pids. gov. ph/ris/pjd/pidsjpd86-labortrans. pdf).

67. FEDER G. The Relation Between Farm Size and Productivity: the role of family labor, supervision, and credit constraints. / Dev Econ 1985; 18: 297-313.

68. ESWARAN M, KOTWAL A. Access to capital and agrarian production organization. Econ / 1986; 96: 482-98

69. CARTER M, WIEBE K. Access to Capital and its Impact on Agrarian Structure and Productivity in Kenya. Am J Agric Econ 1990; 72(5): 1146-50.

70. UY M. Contractual Choice and Internal Organization in Philippine Sugarcane Production. M. A. thesis, University of the Philippines 1979.

71. REARDONT, TIMMER PC, BARRETT CP, BERDEGU'E J. The Rise of Supermarkets in Africa, Asia, and Latin America. Am / Agric Econ 2003; 85: 1140-6.

72. WILLIAMSON O. The economic institutions of capitalism: firms, markets and relational contracting. New York: Free Press, 1985.

73. ROUMASSET J. Land and Labor Contracts in the Philippines: Lessons from the New Institutional Economics. Presented at the Agricultural Organization and Rural Welfare Conference, Philippines, January 1981.

74. DE JANVRY A, FAFCHAMPS M, SADOULET E. Peasant household behavior with missing markets: some paradoxes explained. Econ / 1991; 101: 1400-17.

75. ROUMASSET J, UY M. Piece Rates, Time Rates and Teams: Explaining Patterns in the Employment Relation. / Economic Behavior and Organiz 1980; 1: 343-60.

76. MEYER R, NAGARAJAN G. Rural financial markets in Asia: policies, paradigms and performance. New York: Oxford University Press, 2000.

77. GONZALEZ-VEGA, CLAUDIO. Credit Rationing Behavior of Agricultural Lenders: The Iron Law of Interest-Rate Restrictions. In: Adams DW, Graham DH, Von Pischke JD, eds. Undermining Rural Development with Cheap Credit. Boulder: Westview Press, 1984: 78-96. 
78. SHAW, EDWARD S. Financial Deepening in Economic Development. New York: Oxford University Press, 1973.

79. MCKINNON RI. Money and Capital in Economic Development. Washington DC: Brookings Institution, 1973.

80. STIGLITZ J, UYE. Financial Markets, Public Policy and the East Asian Miracle. World Bank Res Obs 1996; 11(2): 249-76.

81. CONNING J, UDRY C. Rural Financial Markets in Developing Countries. Handbook of Agricultural Economics 3, Chapter 15. 2005.

82. HOFF K, STIGLITZ J. Moneylenders and bankers: price-increasing subsidies in a monopolistically competitive market. I Dev Econ 1998; 55: 485-518.
83. ROUMASSET J. The welfare economics of rural credit and the benefits of land titles. Washington, DC: World Bank. Manuscript. , 1986.

84. GHOSH P, MOOKHERJEE D, RAY D. In: Credit Rationing in Developing Countries: An Overview of the Theory. Readings in the Theory of Economic Development, 2000: 383-401.

85. BOSE P. Formal-informal interaction in rura credit markets. J Development Economics 1998; 56(2).

86. BIRKHAEUSER D, EVENSON R, FEDER G. The Economic Impact of Agricultural Extension: A Review. Econ Dev Cult Change 1991; 39(3): 507-21.
87. EVENSON R. Economic Impact Studies of Agricultural Research and Extension. Yale University, New Haven, Conn. (mimeographed), 1998.

88. OWENS T, HODDINOTT J, KINSEY B. The Impact of Agricultural Extension on Farm Production in Resettlement Areas of Zimbabwe. Econ Dev Cult Change 2003; 51: 337-57.

89. NORTH D, WALLIS J. American government expenditures: a historical perspective. Am Econ Rev 1982; 72(2): 336-40.

90. LIPTON M, RAVALLION M. Poverty and Policy. In: Behrman I, Srinivasan TN, eds. Handbook of Development Economics. Volume 3B. Amsterdam: Elsevier Science, North Holland, 1995: 2553-601. 